\title{
Heart Rate Reduction by Ivabradine Improves Aortic Compliance in Apolipoprotein E-Deficient Mice
}

\author{
Florian Custodis $^{a}$ Peter Fries $^{b} \quad$ Andreas Müller $^{b}$ Christoph Stamm ${ }^{a}$ \\ Markus Grube $^{c}$ Heyo K. Kroemer ${ }^{c}$ Michael Böhm ${ }^{a}$ Ulrich Laufs ${ }^{a}$ \\ Kliniken für a Innere Medizin III, Kardiologie, Angiologie und Internistische Intensivmedizin and ${ }^{b}$ Diagnostische und \\ Interventionelle Radiologie, Universitätsklinikum des Saarlandes, Homburg/Saar, and 'Institut für Pharmakologie, \\ Abteilung Allgemeine Pharmakologie, Ernst-Moritz-Arndt-Universität Greifswald, Greifswald, Germany
}

\section{Key Words}

Apolipoprotein E knockout mice $\cdot$ Heart rate reduction • Ivabradine $\cdot$ Aortic compliance

\begin{abstract}
Background: Impaired vascular compliance is associated with cardiovascular mortality. The effects of heart rate on vascular compliance are unclear. Therefore, we characterized effects of heart rate reduction (HRR) by I(f) current inhibition on aortic compliance and underlying molecular mechanisms in apolipoprotein E-deficient $\left(\mathrm{ApoE}^{-\digamma^{-}}\right)$mice. Methods: ApoE ${ }^{-/}$mice fed a high-cholesterol diet and wild-type (WT) mice were treated with ivabradine $(20 \mathrm{mg} / \mathrm{kg} / \mathrm{d})$ or vehicle for 6 weeks. Compliance of the ascending aorta was evaluated by MRI. Results: Ivabradine reduced heart rate by $113 \pm 31$ bpm $(\sim 19 \%)$ in WT mice and by $133 \pm 6 \mathrm{bpm}(\sim 23 \%)$ in $\mathrm{ApoE}^{-/-}$mice. Compared to WT controls, ApoE ${ }^{-/-}$mice exhibited reduced distensibility and circumferential strain. HRR by ivabradine increased distensibility and circumferential strain in $\mathrm{ApoE}^{-} /^{-}$mice but did not affect both parameters in WT mice. Ivabradine reduced aortic protein and mRNA expression of the angiotensin II type 1 (AT1) receptor and reduced rac1-GTPase activity in $\mathrm{ApoE}^{-/-}$mice. Moreover, membrane translocation of $\mathrm{p} 47^{\mathrm{phox}}$ was inhibited. In $\mathrm{ApoE}^{-/-}$mice, HRR
\end{abstract}

induced anti-inflammatory effects by reduction of aortic mRNA expression of IL-6, TNF-alpha and TGF-beta. Conclusion: HRR by ivabradine improves vascular compliance in $\mathrm{ApoE}^{-/}$mice. Contributing mechanisms include downregulation of the AT1 receptor, attenuation of oxidative stress and modulation of inflammatory cytokine expression.

Copyright $\odot 2012$ S. Karger AG, Basel

\section{Introduction}

Epidemiological evidence suggests that resting heart rate is associated with cardiovascular morbidity and mortality [1]. Subsequently increased resting heart rate has emerged as a risk marker and target for primary and secondary prevention. Experimental and clinical data suggest that sustained elevation of resting heart rate contributes to the pathogenesis of vascular disease. The underlying mechanisms are only partially understood and appear to involve cellular signalling events leading to vascular oxidative stress, endothelial dysfunction and acceleration of atherogenesis [2-5].

The large central arteries play an important physiological role in buffering the cyclic changes in pressure resulting from intermittent ejection of blood. Over a person's

\section{KARGER}

Fax +4161306 1234

E-Mail karger@karger.ch

www.karger.com (c) 2012 S. Karger AG, Basel

$1018-1172 / 12 / 0495-0432 \$ 38.00 / 0$

Accessible online at:

www.karger.com/jvr
Dr. Florian Custodis

Klinik für Innere Medizin III, Kardiologie, Angiologie und Internistische

Intensivmedizin, Universitätsklinikum des Saarlandes

Kirrberger Strasse, DE-66424 Homburg/Saar (Germany)

Tel. +496841 1623000, E-Mail florian.custodis@uks.eu 
lifetime they adapt to mechanical demands and remodel by changing their geometry, structure and elastic properties. Compliance, defined as change in volume for a given change in distending pressure, decreases steadily with vascular aging [6]. Reduced compliance alters arterial pressure and flow dynamics and impacts cardiac performance and coronary perfusion. Aortic stiffness, namely the inverse of compliance, predicts cardiovascular morbidity and mortality in patients with cardiovascular disease [7]. Molecular mechanisms contributing to arterial stiffness may involve activation of the renin-angiotensinaldosterone-system (RAAS), increased vascular oxidative stress and expression of inflammatory molecules $[8,9]$.

As an integral component of pulsatile mechanical stress, heart rate may affect the mechanical properties of large arteries resulting in structural alterations and aggravation of atherosclerotic disease [10]. In experimental studies, accelerated heart rate was shown to affect viscoelastic properties of the vascular wall resulting in the reduction of arterial compliance [11-13]. Apolipoprotein E knockout $\left(\mathrm{ApoE}^{-} /^{-}\right)$mice develop atherosclerotic lesions and exhibit hemodynamic alterations in indexes of vascular resistance and compliance [14]. As direct measurements of aortic compliance, the distensibility (given as the relative change in vessel cross-sectional area over pulse pressure) and the circumferential cyclic strain (which implies the ratio of the systolic and the diastolic vessel circumferences) can be determined by MRI.

The $\mathrm{I}(f)$ current inhibitor ivabradine reduces heart rate without influencing left ventricular contractile function and blood pressure and may be used as a tool to study the effects of heart rate on vascular biology [15]. This study was therefore undertaken to test the hypothesis that selective heart rate reduction (HRR) induced by ivabradine may affect aortic compliance as well as to characterize underlying molecular mechanisms.

\section{Methods}

Animals, Heart Rate and Blood Pressure

Animal experiments were conducted in accordance with institutional guidelines and the German animal protection law. Male ApoE ${ }^{-/}$and C57/Bl6 [wild-type (WT)] mice (Charles River Laboratories, Sulzfeld, Germany) were used for this study. The animals were maintained in a $22^{\circ} \mathrm{C}$ room with a 12 -hour light/ dark cycle and received drinking water and food ad libitum. ApoE $/^{-}$mice were fed a high-fat, cholesterol-rich diet for 6 weeks starting at 12 weeks of age. WT mice received regular chow. At the same age, animals were randomized to oral ivabradine (ivabradine hydrochloride, S 16257-2, Servier, France) (20 mg/kg body weight) or vehicle treatment via drinking water. Six weeks after treatment initiation, heart rate and blood pressure were measured by a computerized tail-cuff system as described [2].

\section{Magnetic Resonance Imaging}

After 6 weeks, drug treatment was terminated and paused for 3 more days to adjust heart rates. Mice were subjected to MRI using a horizontal bore 9.4 Tesla animal scanner (Bruker BioSpin 94/20, Ettlingen, Germany). The MR system was run with ParaVision 5.1 including the IntraGate ${ }^{\circledR} /$ software for the sequence acquisition and reconstruction. All experiments were performed during general anesthesia using a mixture of $1.5-2 \%$ isoflurane and $100 \%$ oxygen with a flow rate of $1.5 \mathrm{l} / \mathrm{min}$. Mice were positioned prone in a dedicated cradle including the 4 -element $(2 \times 2)$ phased-array surface coil (Bruker BioSpin). A water-heated blanket was fixed on the body of the animals to prevent hypothermia and core temperature was measured using a rectal sensor. ECG signal was derived from external electrodes attached to the front paws and a pressure transducer attached to the abdominal wall allowed for monitoring of the respiration rate. We acquired a double-gated bright-blood cine sequence (Intragate Flash, TR/TE $=8.9 / 2.1 \mathrm{~ms}$, flip angle $=$ $10^{\circ}$, field of view $=2 \times 2 \mathrm{~cm}$, matrix $=384 \times 384$ and slice thickness $=1 \mathrm{~mm}$ ) located perpendicular to the ascending aorta beyond the sinus valsalvae at the level of the left pulmonary artery. A total of 25 cine frames of the acquired raw data were reconstructed, displaying one cardiac cycle. Quantitative evaluation of the data included assessment of the cross-sectional vessel lumen at end-systole and end-diastole at the level of the left pulmonary artery. For quantitative evaluation, the acquired image data was transferred to an external workstation and analyzed by a single blinded observer using image evaluation software (OsiriX, Apple Inc., USA). Aortic distensibility was calculated using the formula: distensibility $=($ end-systolic aortic area - end-diastolic aortic area)/(end-diastolic aortic area $\times$ pulse pressure) [16]. Circumferential cyclic strain was calculated using the formula: circumferential cyclic strain $=0.5 \times\left(\mathrm{C}_{S}^{2} / \mathrm{C}_{\mathrm{D}}^{2}-1\right)$ where $\mathrm{C}_{S}$ is the systolic circumference and $C_{D}$ is the diastolic circumference [17].

\section{Histomorphometry}

Aortic wall thickness and medial cross-sectional area (MCSA) were assessed in samples of the thoracic aorta of WT and $\mathrm{ApoE}^{-/^{-}}$ mice after staining with hematoxylin-eosin. Mice were euthanized with an overdose of ketamine/xylazine and perfusion fixed in $4 \%$ formalin. Aortic segments were longitudinally embedded in paraffin and 3 successive sagittal sections $(3 \mu \mathrm{m})$ were stained with hematoxylin-eosin. Wall thickness and MCSA were determined by computer-directed image analysis (NIS-Elements, BR 3.2, Nikon instruments, USA).

\section{Vascular Gene Expression Analysis}

RNA from aortic homogenates was isolated with RNA-clean. One microgram of the isolated total RNA was reverse transcribed using random primers and MMLV reverse transcriptase for 60 min at $42^{\circ} \mathrm{C}$ and $10 \mathrm{~min}$ at $75^{\circ} \mathrm{C}$. Aortic mRNA expression of angiotensin II type 1 (AT1) receptor was quantified with the TaqMan PCR system (Abi Prism 7700 Sequence Detection System, PE Biosystems) using TaqMan probe Mm00616371_ml provided by Applied Biosystems. Real-time RT-PCR using SYBR Green (Applied Biosystems, Darmstadt, Germany) was performed for mm18SrRNA (forward 5'-TCAACACGGGAAACCTCAC-3', reverse 5'-ACCAGACAAATCGCTCCAC-3'), mmIL6 (forward 5'- 
Table 1. Effects of treatment with ivabradine $(20 \mathrm{mg} / \mathrm{kg} /$ day) or vehicle for 6 weeks on heart rate, blood pressure, pulse pressure and the pressure rate product

\begin{tabular}{|c|c|c|c|c|}
\hline & $\begin{array}{l}\text { WT } \\
\text { vehicle }\end{array}$ & $\begin{array}{l}\text { WT } \\
\text { Iva }\end{array}$ & $\begin{array}{l}\text { ApoE } \\
\text { vehicle }\end{array}$ & $\begin{array}{l}\text { ApoE } \\
\text { Iva }\end{array}$ \\
\hline Heart rate, bpm & $606 \pm 25$ & $493 \pm 30^{\mathrm{a}}$ & $583 \pm 20$ & $449 \pm 3^{b}$ \\
\hline $\mathrm{SBP}, \mathrm{mm} \mathrm{Hg}$ & $117 \pm 3$ & $121 \pm 4$ & $114 \pm 5$ & $111 \pm 1$ \\
\hline $\mathrm{DBP}, \mathrm{mm} \mathrm{Hg}$ & $101 \pm 3$ & $107 \pm 6$ & $87 \pm 5$ & $91 \pm 1$ \\
\hline MAP, mm Hg & $106 \pm 3$ & $106 \pm 5$ & $96 \pm 5$ & $97 \pm 1$ \\
\hline $\mathrm{PP}, \mathrm{mm} \mathrm{Hg}$ & $16 \pm 2$ & $14 \pm 2$ & $28 \pm 3^{c}$ & $20 \pm 3^{\mathrm{d}}$ \\
\hline \multicolumn{5}{|l|}{$\mathrm{PP} \times \mathrm{HR}$} \\
\hline $10^{3} \times \mathrm{mm} \mathrm{Hg} \times \mathrm{bpm}$ & $9.8 \pm 2$ & $7.4 \pm 0.8$ & $16.1 \pm 2^{\mathrm{e}}$ & $9.1 \pm 0.1^{\mathrm{f}}$ \\
\hline
\end{tabular}

Data appear as mean \pm SEM. Per group: $\mathrm{WT} \mathrm{n}=5, \mathrm{ApoE}^{-{ }^{-} \mathrm{n}}=10 . \mathrm{DBP}=$ Diastolic blood pressure; MAP $=$ middle arterial pressure; $\mathrm{PP}=$ pulse pressure; $\mathrm{SBP}=$ systolic blood pressure.

${ }^{\mathrm{a}} \mathrm{p}<0.05$ vs. WT vehicle. ${ }^{\mathrm{b}} \mathrm{p}<0.001$ vs. ApoE $/^{-}$vehicle. ${ }^{\mathrm{c}} \mathrm{p}<0.05$ vs. WT vehicle. ${ }^{\mathrm{d}} \mathrm{p}<0.05$ vs. ApoE $/^{-} \mathrm{ve}^{-}$ hicle. ${ }^{\mathrm{e}} \mathrm{p}<0.05$ vs. WT vehicle. ${ }^{\mathrm{f}} \mathrm{p}<0.01$ vs. ApoE ${ }^{-}{ }^{-}$vehicle.

TCCTACCCCAATTTCCAATG-3', reverse 5'-ACCACAGTGAGGAATGTCCA-3'), mmTNF-alpha (forward 5'-GATTATGGCTCAGGGTCCAA-3', reverse 5'- CTCCCTTTGCAGAACTCAGG-3') and mmTGF-beta (forward $5^{\prime}$-AGCCCGAAGCGGACTACTAT-3', reverse 5'-TCCACATGTTGCTCCACACT-3'). Expression was normalized to $18 \mathrm{~S}$ ribosomal RNA.

\section{Western Blotting}

Immunoblotting for AT1 receptor (ab47162, Abcam, UK),

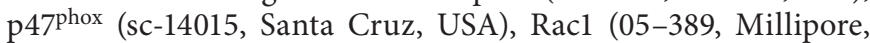
USA) and GAPDH (sc-32233, Santa Cruz) to control for equal protein loading was performed as described [18]. Rac1 GST-PAK pull down assays to determine Racl activity and membrane preparations were performed as described [18].

\section{Angiotensin II Concentration and Angiotensin-Converting} Enzyme Activity

Serum angiotensin II concentration was determined by ELISA using Assay Max from Assay Pro (USA). Serum angiotensin-converting enzyme (ACE) activity was determined by a colorimetric test using an enzymatic assay kit from Bühlmann (Switzerland).

\section{Statistical Analysis}

Results are presented as mean \pm SEM. The unpaired Student $t$ test and ANOVA for multiple comparisons were employed where applicable. Post hoc comparisons were performed with the Newman-Keuls test. Values of $\mathrm{p}<0.05$ were considered statistically significant.

\section{Results}

\section{Heart Rate Reduction by Ivabradine}

Twelve-week-old WT and $\mathrm{ApoE}^{-/}{ }^{-}$mice were randomized to ivabradine $(20 \mathrm{mg} / \mathrm{kg}$ body weight) or vehicle for 6 weeks. Table 1 shows mean heart rates, systolic and diastolic blood pressures after 6 weeks of treatment. Ivabra- dine decreased heart rate by $19 \%(113 \pm 31 \mathrm{bpm})$ in WT and 23\% (133 $\pm 6 \mathrm{bpm})$ in $\mathrm{ApoE}^{-/^{-}}$mice. Systolic, diastolic and mean arterial blood pressures were not altered significantly, whereas pulse pressure and the pressure rate product were reduced in the group of ivabradinetreated $\mathrm{ApoE}^{-/}$mice.

\section{Heart Rate Reduction Improves Aortic Distensibility and Circumferential Cyclic Strain}

As direct measurements of aortic compliance, the distensibility and the circumferential cyclic strain were determined by MRI. Drug treatment was discontinued 3 days in advance to adjust heart rates. In contrast to agematched WT controls, ApoE $/^{-}$mice exhibited reduced distensibility $\left(0.029 \pm 0.00210^{-3} \mathrm{~mm} \mathrm{Hg}^{-1}\right.$ vs. $0.015 \pm$ $0.0011^{-3} \mathrm{~mm} \mathrm{Hg}^{-1}, \mathrm{p}<0.01$ ) (fig. 1g). HRR by ivabradine markedly attenuated the decrease of distensibility in ApoE ${ }^{-/}$mice to $0.024 \pm 0.00210^{-3} \mathrm{~mm} \mathrm{Hg}^{-1}(\mathrm{p}<0.01)$ (fig. 1e-g). Circumferential cyclic strain was markedly reduced in $\mathrm{ApoE}^{-/-}$mice compared to WT controls (33.8 \pm $3 \%$ vs. $19.5 \pm 1 \%, \mathrm{p}<0.01)$. Treatment with ivabradine increased circumferential strain compared to untreated ApoE $^{-/^{-}}$mice $(28.1 \pm 3 \%, \mathrm{p}<0.01)$ (fig. 1h). In contrast to $A \mathrm{poE}^{-} /^{-}$mice, HRR did not affect distensibility and circumferential cyclic strain in WT mice.

To rule out changes in vascular wall morphology that could account for the increase in aortic compliance induced by HRR wall thickness and MCSA were assessed in samples of the thoracic aorta after staining with hematoxylin-eosin. Wall thickness and MCSA did not differ between vehicle-treated $\mathrm{WT}$ and $\mathrm{ApoE}^{-l^{-}}$mice [wall thickness $(\mu \mathrm{m})$ : WT $34.1 \pm 1$ vs. $\mathrm{ApoE}^{-/-} 34.9 \pm 2$ and 
Fig. 1. Effect of HRR on aortic distensibility and circumferential cyclic strain. a MRI through the mouse heart and ascending aorta. The line indicates the position of the acquired sequence for the assessment of cross-sectional vessel area measurement. b Representative cine sequence perpendicular to the ascending aorta at the level of the pulmonary trunk. c-f Representative cross sections of enddiastolic (ED) and end-systolic (ES) aortic vessel area in vehicle- $(\mathbf{c}, \mathbf{d})$ and ivabradine-treated (e,f) ApoE $^{-/^{-}}$mice. Quantification of aortic distensibility (g) and circumferential cyclic strain (h). i-I Representative aortic sections of WT and $\mathrm{ApoE}^{-{ }^{-}}$mice ( $\mathrm{n}=5$ per group) stained with hematoxylin-eosin (mean \pm SEM; ${ }^{*} \mathrm{p}<0.01$ vs. WT; ${ }^{* *} \mathrm{p}<0.01$ vs. ApoE ${ }^{-}$ vehicle; per group: WT $\mathrm{n}=5$ and $\mathrm{ApoE}^{-/}$ $\mathrm{n}=8)$.
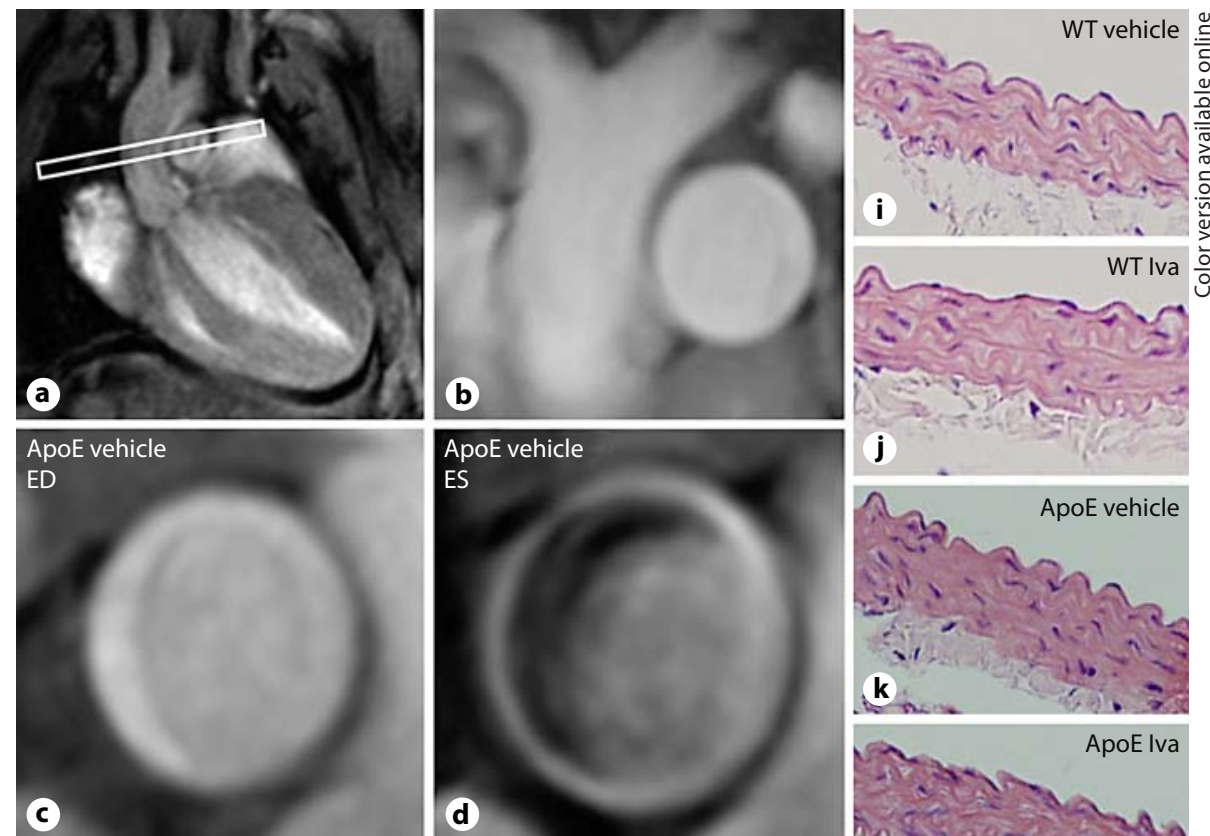

ApoE vehicle

ES


ApoE Iva

ES
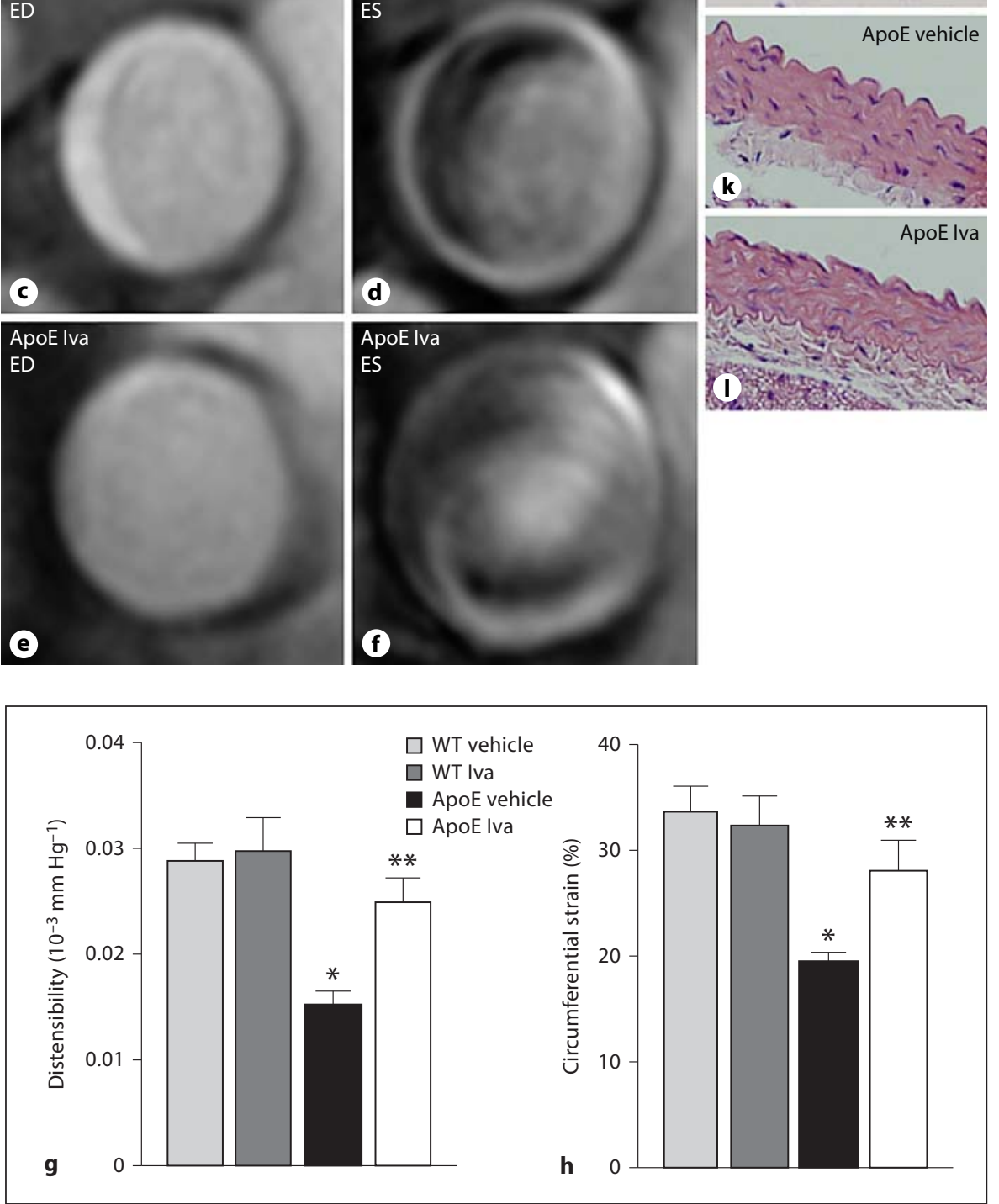

$\operatorname{MCSA}\left(\times 10^{3} \mu \mathrm{m}^{2}\right)$ : WT $78.6 \pm 2$ vs. ApoE $\left.{ }^{-/^{-}} 79.5 \pm 4\right]$. Neither parameter was affected by HRR in WT or $\mathrm{ApoE}^{-} /^{-}$mice [wall thickness $(\mu \mathrm{m})$ : WT $33.2 \pm 2$ vs. $\mathrm{ApoE}^{-/} 35.9 \pm 4$ and $\mathrm{MCSA}\left(\times 10^{3} \mu \mathrm{m}^{2}\right): 76.6 \pm 3 \mathrm{vs}$. $81.4 \pm 3$ ] (fig. 1i-1).

\section{Ivabradine Reduces Aortic AT1 Receptor Expression}

To address the effects of HRR on the RAAS serum activity of the ACE and concentration of angiotensin II (ANG II) was investigated in WT and in $\mathrm{ApoE}^{-/}$mice. In addition, mRNA and protein expression of the AT1 
Fig. 2. Effect of HRR on angiotensin II concentration (a), serum ACE activity (b) and aortic AT1 receptor expression (c-e). Representative Western blot and quantification of AT1 receptor protein expression (c, d) and mRNA expression (e) (mean \pm SEM; ${ }^{*} \mathrm{p}<0.01$ vs. WT; ${ }^{*} \mathrm{p}<0.05$ $\mathrm{ApoE}^{-/^{-}}$vehicle; per group: $\mathrm{WT} \mathrm{n}=5$ and $\left.\mathrm{ApoE}^{-} /^{-} \mathrm{n}=10\right)$.

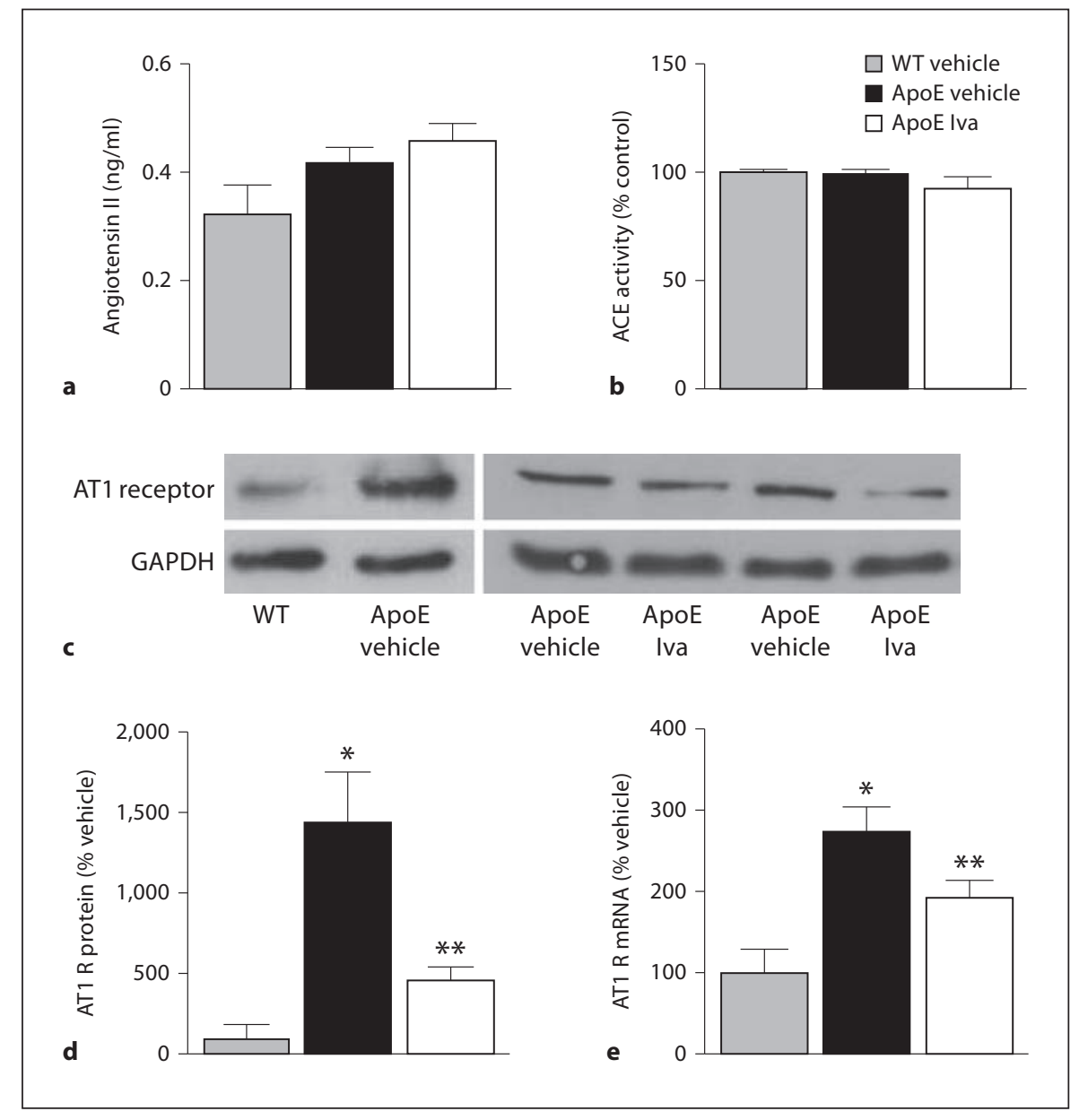

receptor was investigated in aortic homogenates. HRR with ivabradine did not alter angiotensin II concentration or ACE activity in the serum of $\mathrm{ApoE}^{-/^{-}}$mice (fig. 2a, b). Western blotting and TaqMan PCR demonstrated markedly increased expressions of the AT1 receptor in the thoracic aorta of ApoE $/^{-}$mice compared to WT controls which were significantly attenuated by ivabradine. In detail, ivabradine decreased protein expression to 453 $\pm 91 \%$ (vehicle $1420 \pm 320 \%, \mathrm{p}<0.05$ ) (fig. $2 \mathrm{c}$, d) and mRNA expression to $191 \pm 22 \%$ (vehicle $274 \pm 30 \%$, $\mathrm{p}<0.05$ ) (fig. 2e).

\section{Heart Rate Reduction Attenuates Racl Activity and Membrane Translocation of $p 47^{\text {phox }}$}

A major source of superoxide radicals in the vascular wall, the NADPH oxidase, was shown to be affected by heart rate [2]. The activity of the small GTP-binding protein racl and the membrane translocation of the cytosolic regulatory subunit $\mathrm{p} 47^{\mathrm{phox}}$ are prerequisites for
NADPH oxidase activation and subsequent reactive oxygen species (ROS) production. Protein expressions of racl and $47^{\text {phox }}$ were upregulated in $\mathrm{ApoE}^{-l^{-}}$mice compared to WT controls (fig. 3a), but were not affected by ivabradine. Rac1 GST-PAK pull-down assays were performed to quantify racl activity in aortic homogenates. HRR with ivabradine decreased racl activity to 41 $\pm 3 \%$ of vehicle-treated $\mathrm{ApoE}^{-/^{-}}$mice $(\mathrm{p}<0.05)$ (fig. 3 $\mathrm{b}, \mathrm{c})$. Moreover, ivabradine decreased membrane translocation of $\mathrm{p}^{\text {phox }} \mathrm{p}^{\text {to }} 39 \pm 5 \%$ in $\mathrm{ApoE}^{-/^{-}}$mice (fig. $3 \mathrm{~b}$, d) $(\mathrm{p}<0.05)$.

\section{Inflammatory Cytokines and TGF-Beta Are \\ Modulated by Ivabradine}

Inflammation plays a central role in the pathogenesis of atherosclerosis and may contribute to the stiffening of large arteries via changes in the composition of the arterial wall [19]. We previously characterized heart-rate-dependent anti-inflammatory effects in $\mathrm{ApoE}^{-/}$mice [2, 
Fig. 3. Effect of HRR on aortic racl activity and membrane translocation of $\mathrm{p} 47^{\text {phox }}$. a Representative Western blots of racl and p47phox . b Representative Western blots of rac1 GST-PAK pull-down assays and membrane preparation of $\mathrm{p} 47^{\text {phox }}$. Quantification of racl activity (c) and quantification of membrane translocation of p47phox $\left(\right.$ d) $\left(\right.$ mean \pm SEM; ${ }^{*} \mathrm{p}<0.05$ vs. $\mathrm{ApoE}^{-/^{-}}$vehicle, $\mathrm{n}=4$ per group).



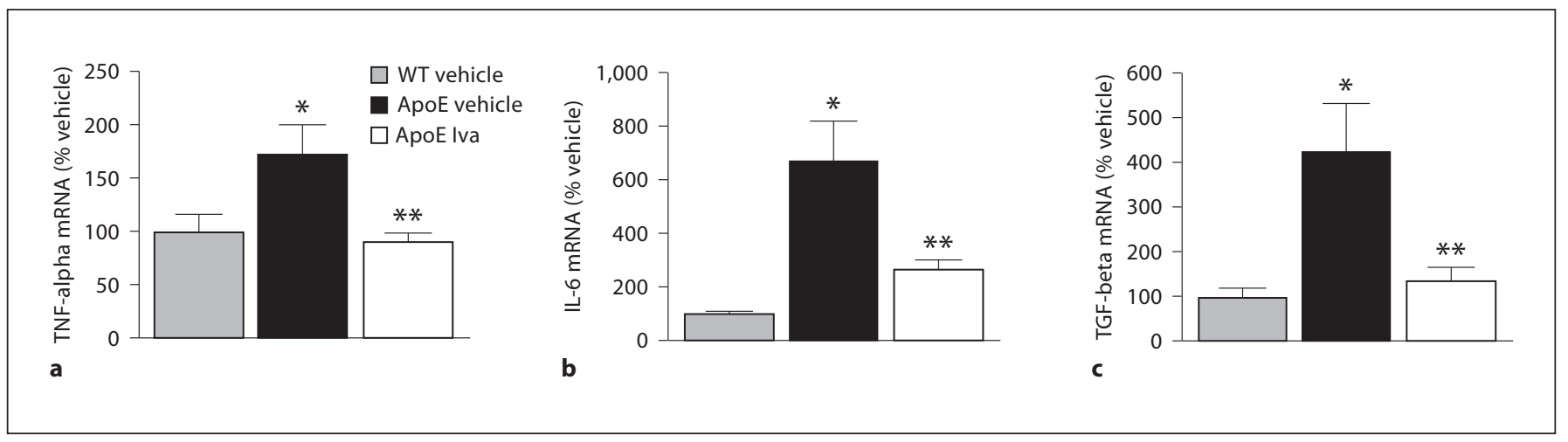

Fig. 4. Effect of HRR on aortic expression of inflammatory cytokines and TGF-beta. Quantification of mRNA expression of TNF-

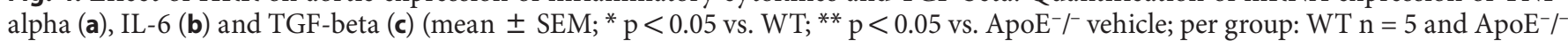
$\mathrm{n}=8)$. 
20] and characterized the aortic expression of TNF-alpha, IL- 6 and TGF-beta consecutively.

Real-time RT-PCR demonstrated markedly increased expressions of TNF-alpha, IL-6 and TGF-beta in ApoE ${ }^{-/}$ mice compared to WT controls $(\mathrm{p}<0.05)$. HRR attenuated the expression of inflammatory gene expression in the thoracic aorta of ApoE ${ }^{-} /{ }^{-}$mice after 6 weeks of treatment with ivabradine. In detail, ivabradine decreased the expression of TNF-alpha to $90 \pm 9 \%\left(\mathrm{ApoE}^{-/^{-}}\right.$vehicle $171 \pm 30 \%, \mathrm{p}<0.05)$, IL-6 to $263 \pm 35 \%\left(\mathrm{ApoE}^{-/^{-}}\right.$vehicle $667 \pm 140 \%, \mathrm{p}<0.05)$ and TGF-beta to $134 \pm 31 \%$ $\left(\mathrm{ApoE}^{-/^{-}}\right.$vehicle $\left.421 \pm 109 \%, \mathrm{p}<0.05\right)$ of vehicle (fig. $4 a-c)$.

\section{Discussion}

The data show that the vascular phenotype of hyperlipidemic $\mathrm{ApoE}^{-/}$mice is characterized by impairment of central vascular distensibility and circumferential cyclic strain. Sustained HRR induced by the $\mathrm{I}(f)$ current inhibitor ivabradine improves aortic distensibility and strain and preserves aortic compliance. Ivabradine reduced aortic expression of the AT1 receptor, decreased Racl activity and prevented membrane translocation of $\mathrm{p} 47^{\text {phox }}$. Moreover, the expression of inflammatory cytokines and TGF-beta was markedly reduced.

Evidence for a causal association between increased resting heart rate and arterial stiffness derives from cross-sectional studies demonstrating an association between heart rate and increased pulse wave velocities $[13,21]$. Direct effects of accelerated heart rate on arterial compliance have been investigated in several experimental settings. In rats and humans, progressive increases in heart rate induced by atrial pacing led to stiffening of elastic- and muscle-type arteries [11, 12, 22]. The inverse - the effect of HRR - was tested in rodents using ivabradine. In dyslipidemic mice and in rats, HRR by ivabradine or metoprolol reduced vascular stiffness $[23,24]$. The data here characterized central aortic elasticity in $\mathrm{ApoE}^{-/^{-}}$mice, an animal model that has been well characterized regarding lipid-induced alterations and which is affected by enhanced vascular stiffness in the absence of elevated blood pressure [14]. High cholesterol-fed $\mathrm{ApoE}^{-/^{-}}$mice exhibit a markedly reduced aortic compliance compared to their WT littermates. Sustained HRR by ivabradine attenuates a decrement of distensibility and restores circumferential cyclic strain. This effect is accompanied by a reduction in arterial pulse pressure which has been shown to be closely re- lated to vascular wall stiffness [25]. Ivabradine has no negative effect on the distensibility of healthy arteries in WT mice.

Mechanistically, the elastic behavior of the thoracic aorta is determined by structural components of the arterial wall, largely by the medial layer. Albaladejo et al. [24] tested the effects of HRR with ivabradine on the morphology of the thoracic aorta of spontaneously hypertensive rats. Ivabradine mediated antihypertrophic effects in terms of regression of media thickness and MCSA. However, in this study, HRR with ivabradine exerted no effect on MCSA or wall thickness in WT or in $\mathrm{ApoE}^{-/}$mice. Basically, this finding may be due to the atherosclerotic phenotype which is not primarily focused on alterations of the medial layer in contrast to the hypertensive vascular phenotype.

Beyond structural properties, vascular tone and compliance are significantly influenced by endothelial function. Several studies suggest that endothelial dysfunction and reduced nitric oxide bioavailability contribute to arterial stiffening [26-28]. Recently, HRR by I $f(f)$ current inhibition was shown to improve endothelial-dependent vasorelaxation in different types of mice and disease models, and ivabradine was characterized as an effective tool to conserve endothelial function $[2-5,23]$. Since heart rates were matched before MRI, the observed effects reflect chronic alterations. We thus suggest that the primary mechanism by which ivabradine restores vascular compliance is an improvement of endothelial-dependent vasorelaxation.

Clinical and experimental evidence links the RAAS to vascular stiffness. The enhanced activity of different RAAS components was shown to contribute to reduced vascular compliance via a multitude of vascular alterations [8]. In this study in $\mathrm{ApoE}^{-/-}$mice, expression of the AT1 receptor, the predominant mediator of maladaptive RAAS effects, was markedly downregulated on mRNA and protein levels by selective HRR. Besides a relevant number of classic agonists known to regulate RAAS activity and AT1 receptor expression in vascular cells, hemodynamic and mechanical forces may interact with the RAAS or may even stimulate its activity [29-31]. Cyclic mechanical stress, the transmural force imposed on the vessel wall, was shown to increase AT1 receptor activity and expression independently of angiotensin II in vascular smooth-muscle cells and cardiomyocytes [30, 31]. Bolduc et al. [23] investigated the effect of heart rate on carotid artery stiffness in dyslipidemic mice and demonstrated that heart-rate-associated mechanical stress directly contributes to carotid artery stiffening. In turn, the 
reduction of mechanical stress via HRR with ivabradine or metoprolol reduced carotid stiffness. In view of these findings, though not directly evaluated, our data provide evidence for a functional link between mechanical wall stress and AT1 receptor expression in the thoracic aorta of $\mathrm{ApoE}^{-/-}$mice.

A hemodynamic force that might be affected by heart rate, although not clarified experimentally, is wall shear stress. Lehoux et al. [29] detected a pronounced expression of the AT1 receptor in the inner atheroprone region of the aortic arch characterized by low wall shear stress. Moreover, they showed that laminar shear stress downregulates AT1 receptor expression in human umbilicalvein endothelial cells. Evidence for a potential link between shear stress and heart rate originates from in vitro studies suggesting that shear waveform, and particularly shear frequency, can determine endothelial-cell gene expression profiles. A 'physiological' shear frequency of 1 $\mathrm{Hz}(1 / \mathrm{s} \sim 60 / \mathrm{min})$ repressed inflammatory transcripts and induced several atheroprotective transcripts in vascular endothelial cells [32]. However, since substantial experimental evidence for a connection between shear stress and heart rate is still lacking, one may speculate that increased heart rate promotes disturbed (e.g. oscillatory) flow that may be 'redirected' to more laminar flow by HRR. A hypothesis that remains to be evaluated by future research.

Studies on isolated vascular endothelial and smoothmuscle cells as well as in vivo experiments showed that pulsatile mechanical signals are capable of inducing the release of ROS [33]. A recently published study linked oxidative stress to impaired arterial elasticity in healthy subjects without confounding risk factors [34]. Previous experiments by our group demonstrated that NADPH oxidase activity was downregulated in the aorta of ivabradine-treated $\mathrm{ApoE}^{-/-}$mice [2]. Consequently, in this study, we tested for effects on NADPH subunits, Racl and p $47^{\text {phox }}$ which are essential for NADPH-associated ROS release. HRR negatively affected racl activity and reduced $\mathrm{p} 47^{\text {phox }}$ membrane translocation. These findings contribute to the established antioxidative effects of ivabradine on the vasculature and extend the mechanisms by which increased heart rate mediates atheroprone effects.

Biomarkers of inflammation like CRP, interleukin-6 and TNF-alpha have been associated positively with measures of arterial stiffness in studies in apparently healthy individuals and in groups of patients with cardiovascular disease [35]. Inflammatory molecules are involved in several stages of vascular stiffening [9]. In vascular cells, cy- clic stretch at pathological amplitudes induced distinct expression patterns of genes involved in inflammatory responses [36]. Here we describe a reduction of inflammatory cy tokine expression by HRR. These anti-inflammatory effects support our earlier findings of a potent downregulation of inflammatory cytokines by ivabradine in $\mathrm{ApoE}^{-/^{-}}$mice $[2,20]$. TGF-beta acts as a central player in the development of fibrosis in chronic inflammatory conditions [9]. Corresponding to IL- 6 and TNFalpha, mRNA expression of TGF-beta was reduced by ivabradine, confirming a robust effect of reduced heart rate on the signaling events leading to vascular stiffness.

In conclusion, chronic HRR induced by $\mathrm{I}(f)$ current inhibition restores aortic compliance in a mouse model of lipid-induced atherosclerosis. Signaling associated with arterial stiffening involves the combined influences of several distinctive pathways and external risk factors. Here we show positive effects on the RAAS, oxidative stress and inflammation. HRR reduces AT1 receptor expression, attenuates vascular oxidative stress via reduced racl activity and $\mathrm{p} 47^{\text {phox }}$ membrane translocation and modulates vascular inflammatory cytokine expression. As previous experiments ruled out direct effects of ivabradine on cultured vascular cells and aortic ring preparations $[2,20]$, sustained HRR and potentially associated vascular mechanical modifications are likely the primary mechanisms at work. Although a causative association between the expression of molecular targets and aortic stiffness could not be verified, the results provide evidence for a strong functional link between heart rate and vascular stiffening in the thoracic aorta of $\mathrm{ApoE}^{-/}$mice that may be reduced by ivabradine, a hypothesis that is still to be tested in a clinical trial.

\section{Acknowledgements}

We are indebted to Ellen Becker and Simone Jäger for excellent technical assistance. This work was supported by the German Heart Foundation/German Foundation of Heart Research (F/14/11 to F.C.), the Deutsche Forschungsgemeinschaft (DFG KFO 196 to U.L. and M.B.) and the Universität des Saarlandes (Homburger Forschungsförderungsprogramm, HOMFOR).

\section{Disclosure Statement}

The Universität des Saarlandes has received an unrestricted grant from Servier (France). M.B. has received honoraria from Servier (France) and is a member of the Executive Board of the SHIfT-Trial. 


\section{References}

1 Custodis F, Schirmer SH, Baumhäkel M, Heusch G, Böhm M, Laufs U: Vascular pathophysiology in response to increased heart rate. J Am Coll Cardiol 2010;56:19731983.

-2 Custodis F, Baumhäkel M, Schlimmer N, List F, Gensch C, Böhm M, Laufs U: Heart rate reduction by ivabradine reduces oxidative stress, improves endothelial function, and prevents atherosclerosis in apolipoprotein E-deficient mice. Circulation 2008;117: 2377-2387.

- 3 Drouin A, Gendron ME, Thorin E, Gillis MA, Mahlberg-Gaudin F, Tardif JC: Chronic heart rate reduction by ivabradine prevents endothelial dysfunction in dyslipidaemic mice. Br J Pharmacol 2008;154:749-757.

-4 Baumhäkel M, Custodis F, Schlimmer N, Laufs U, Böhm M: Heart rate reduction with ivabradine improves erectile dysfunction in parallel to decrease in atherosclerotic plaque load in ApoE-knockout mice. Atherosclerosis 2010;212:55-62.

$\checkmark 5$ Custodis F, Gertz K, Balkaya M, Prinz V, Mathar I, Stamm C, Kronenberg G, Kazakov A, Freichel M, Böhm M, Endres M, Laufs U: Heart rate contributes to the vascular effects of chronic mental stress: effects on endothelial function and ischemic brain injury in mice. Stroke 2011;42:1742-1749.

-6 O’Rourke MF, Hashimoto J: Mechanical factors in arterial aging: a clinical perspective. J Am Coll Cardiol 2007;50:1-13.

7 Cavalcante JL, Lima JA, Redheuil A, Al-Mallah $\mathrm{MH}$ : Aortic stiffness: current understanding and future directions. J Am Coll Cardiol 2011;57:1511-1522.

$\checkmark 8$ Lacolley P, Safar ME, Regnault V, Frohlich ED: Angiotensin II, mechanotransduction, and pulsatile arterial hemodynamics in hypertension. Am J Physiol Heart Circ Physiol 2009;297:H1567-1575.

-9 Zieman SJ, Melenovsky V, Kass DA: Mechanisms, pathophysiology, and therapy of arterial stiffness. Arterioscler Thromb Vasc Biol 2005;25:932-943.

10 Bassiouny HS, Zarins CK, Kadowaki MH, Glagov S: Hemodynamic stress and experimental aortoiliac atherosclerosis. J Vasc Surg 1994;19:426-434.

- 11 Giannattasio C, Vincenti A, Failla M, Capra A, Ciro A, De Ceglia S, Gentile G, Brambilla $R$, Mancia G: Effects of heart rate changes on arterial distensibility in humans. Hypertension 2003;42:253-256.

-12 Mircoli L, Mangoni AA, Giannattasio C, Mancia G, Ferrari AU: Heart rate-dependent stiffening of large arteries in intact and sympathectomized rats. Hypertension 1999;34: 598-602.

$\checkmark 13$ Sa Cunha R, Pannier B, Benetos A, Siche JP, London GM, Mallion JM, Safar ME: Association between high heart rate and high ar- terial rigidity in normotensive and hypertensive subjects. J Hypertens 1997;15:14231430.

14 Hartley CJ, Reddy AK, Madala S, MartinMcNulty B, Vergona R, Sullivan ME, HalksMiller M, Taffet GE, Michael LH, Entman ML, Wang YX: Hemodynamic changes in apolipoprotein E-knockout mice. Am J Physiol Heart Circ Physiol 2000;279:H23262334.

15 Du XJ, Feng X, Gao XM, Tan TP, Kiriazis H, Dart AM: I(f) channel inhibitor ivabradine lowers heart rate in mice with enhanced sympathoadrenergic activities. Br J Pharmacol 2004;142:107-112.

-16 Hundley WG, Kitzman DW, Morgan TM, Hamilton CA, Darty SN, Stewart KP, Herrington DM, Link KM, Little WC: Cardiac cycle-dependent changes in aortic area and distensibility are reduced in older patients with isolated diastolic heart failure and correlate with exercise intolerance. J Am Coll Cardiol 2001;38:796-802.

17 Morrison TM, Choi G, Zarins CK, Taylor CA: Circumferential and longitudinal cyclic strain of the human thoracic aorta: age-related changes. J Vasc Surg 2009;49:1029-1036.

18 Custodis F, Eberl M, Kilter H, Böhm M, Laufs U: Association of RhoGDIalpha with Rac1 GTPase mediates free radical production during myocardial hypertrophy. Cardiovasc Res 2006;71:342-351.

$\checkmark 19$ Libby P: Inflammation in atherosclerosis. Nature 2002;420:868-874.

20 Schirmer SH, Degen A, Baumhäkel M, Custodis F, Schuh L, Kohlhaas M, Friedrich E, Bahlmann F, Kappl R, Maack C, Böhm M, Laufs U: Heart-rate reduction by $\mathrm{I}(f)$-channel inhibition with ivabradine restores collateral artery growth in hypercholesterolemic atherosclerosis. Eur Heart J 2012;33: 1223-1231.

21 McEniery CM, Spratt M, Munnery M, Yarnell J, Lowe GD, Rumley A, Gallacher J, BenShlomo Y, Cockcroft JR, Wilkinson IB: An analysis of prospective risk factors for aortic stiffness in men: 20-year follow-up from the caerphilly prospective study. Hypertension 2010;56:36-43.

-22 Mangoni AA, Mircoli L, Giannattasio C, Ferrari AU, Mancia G: Heart rate-dependence of arterial distensibility in vivo. J Hypertens 1996;14:897-901.

23 Bolduc V, Drouin A, Gillis MA, Duquette N, Thorin-Trescases N, Frayne-Robillard I, Des Rosiers C, Tardif JC, Thorin E: Heart rate-associated mechanical stress impairs carotid but not cerebral artery compliance in dyslipidemic atherosclerotic mice. Am J Physiol Heart Circ Physiol 2011;301:H20812092.

24 Albaladejo P, Carusi A, Apartian A, Lacolley P, Safar ME, Benetos A: Effect of chronic heart rate reduction with ivabradine on carotid and aortic structure and function in normotensive and hypertensive rats. J Vasc Res 2003;40:320-328.

25 Dart AM, Kingwell BA: Pulse pressure - a review of mechanisms and clinical relevance. J Am Coll Cardiol 2001;37:975-984.

26 Wilkinson IB, Qasem A, McEniery CM, Webb DJ, Avolio AP, Cockcroft JR: Nitric oxide regulates local arterial distensibility in vivo. Circulation 2002;105:213-217.

27 Wilkinson IB, MacCallum H, Cockcroft JR, Webb DJ: Inhibition of basal nitric oxide synthesis increases aortic augmentation index and pulse wave velocity in vivo. Br J Clin Pharmacol 2002;53:189-192.

28 Wallace SM, Yasmin, McEniery CM, MakiPetaja KM, Booth AD, Cockcroft JR, Wilkinson IB: Isolated systolic hypertension is characterized by increased aortic stiffness and endothelial dysfunction. Hypertension 2007;50:228-233.

29 Ramkhelawon B, Vilar J, Rivas D, Mees B, de Crom R, Tedgui A, Lehoux S: Shear stress regulates angiotensin type 1 receptor expression in endothelial cells. Circ Res 2009;105: 869-875.

30 Stanley AG, Patel H, Knight AL, Williams B: Mechanical strain-induced human vascular matrix synthesis: the role of angiotensin II. J Renin Angiotensin Aldosterone Syst 2000;1: 32-35.

- 31 Zou Y, Akazawa H, Qin Y, Sano M, Takano $\mathrm{H}$, Minamino T, Makita N, Iwanaga K, Zhu W, Kudoh S, Toko H, Tamura K, Kihara M, Nagai T, Fukamizu A, Umemura S, Iiri T, Fujita T, Komuro I: Mechanical stress activates angiotensin II type 1 receptor without the involvement of angiotensin II. Nat Cell Biol 2004;6:499-506.

32 Himburg HA, Dowd SE, Friedman MH: Frequency-dependent response of the vascular endothelium to pulsatile shear stress. Am J Physiol Heart Circ Physiol 2007;293:H645H653.

33 Lehoux S: Redox signalling in vascular responses to shear and stretch. Cardiovasc Res 2006;71:269-279.

34 Patel RS, Al Mheid I, Morris AA, Ahmed Y, Kavtaradze N, Ali S, Dabhadkar K, Brigham K, Hooper WC, Alexander RW, Jones DP, Quyyumi AA: Oxidative stress is associated with impaired arterial elasticity. Atherosclerosis 2011;218:90-95.

35 Lieb W, Larson MG, Benjamin EJ, Yin X, Tofler GH, Selhub J, Jacques PF, Wang TJ, Vita JA, Levy D, Vasan RS, Mitchell GF: Multimarker approach to evaluate correlates of vascular stiffness: the Framingham heart study. Circulation 2009;119:37-43.

-36 Birukov KG: Cyclic stretch, reactive oxygen species, and vascular remodeling. Antioxid Redox Signal 2009;11:1651-1667. 